DOI: $10.31393 /$ reports-vnmedical-2019-23(3)-31

UDC: 616.517 .8

\title{
CONSTITUTIONAL FEATURES OF THE OCCURRENCE AND COURSE OF PSORIASIS (ANALYSIS OF SCIENTIFIC LITERATURE)
}

\section{Obadeh Bassam Abdel-Rahman Al-Qaraleh}

National Pirogov Memorial Medical University, Vinnytsya (Pirogov street, 56, Vinnytsia, Ukraine, 21018)

Received: June 3, 2019; Accepted: July 30, 2019

Responsible for correspondence: e-mail: Dr.obadabassam@gmail.com

Annotation. The purpose of the work is to analyze the scientific literature on the constitutional features of the occurrence and course of psoriasis. The analysis of modern scientific literature in the scientific databases PubMed, eLIBRARY.RU and Web of Science was carried out. A review of the literature indicates the current state of the problem of such a disease as psoriasis, which is not only a skin lesion but also a serious socio-psychological problem. Given its chronic nature, lack of etiopathogenetic treatment, and knowing the trigger factors in the right way, it would be a good idea to look for early predisposition for the disease and to form risk groups for such individuals. Ideal in terms of efficiency and cheapness, given the results of the above studies, could be anthropological studies. The study of the constitutional features of the occurrence and course of psoriasis for the population of Ukraine is thus a priority and topical area of research.

Keywords: psoriasis, occurrence, course, clinical anthropology, quality of life.

Psoriasis is a chronic disease of the autoimmune nature, characterized by the formation of patches on the skin of the skin, which are usually red, dry to the touch and scaly. Today, there is a consensus that psoriasis is a genetically conditioned disease, the trigger for which are certain environmental factors $[1,4]$.

The prevalence of the disease has spread throughout the world, but it is heterogeneous across countries and continents and across age groups [29].

Thus, the WHO global psoriasis report, based on a study of 15 electronic medical bases (the final results were 76 observations from 20 countries), indicated that the prevalence of psoriasis in adults is from $0.51 \%$ to $11.43 \%$, and in children from $0 \%$ up to $1.37 \%$ [24].

Parisi R. et al [25] reported the following data: for children, prevalence ranges from $0 \%$ in Taiwan to $2.1 \%$ in children in Italy; for adults, from $0.91 \%$ in the US to $8.5 \%$ in the Norwegian population. The incidence rate for children living in the US is $40.8 / 100,000$ person-years; for adults from 78.9 / 100.000 person-years in the United States to $230 / 100.000$ person-years in Italy.

In the US, a survey of 6218 people over the age of 20 found that psoriasis prevalence for this age group was 3.2 \% (95\% confidence interval (Cl) $2.6 \%-3.7 \%$ ). In 2010, 7.2 million adults became ill with psoriasis in the United States. The racial sampling survey revealed the highest prevalence rates in Europeoids - $3.6 \%$ (95\% Cl $2.7 \%-4.4 \%)$, lower African-Americans - $1.9 \%$ (95\% Cl $1.0 \%-2.8 \%)$, Latinos $1.6 \%$ (95\% Cl 0.5\%-2.8\%) and other nationalities $1.4 \%$ (95\% Cl $0.3 \%-2.6 \%$ ) [27].

Such a high prevalence and inability to cure this disease requires a modern medical approach based on scientific and clinical thinking. This approach is clinical anthropology.

The purpose of our study is to analyze the current scientific literature on the constitutional features of the occurrence and course of psoriasis.
At present, sufficient knowledge has been accumulated through numerous studies in the world to reveal the individual variability of the morphological parameters of patients with psoriasis [10, 21, 26].

A team of Spanish scientists [6] examined 1162 patients with moderate and severe psoriasis who were undergoing treatment and those in the control group of healthy individuals. Obesity prevalence was found to be significantly higher in patients with psoriasis than in the general population of Spain $(p<0.001)$. Statistical analysis showed that a 5-unit increase in $\mathrm{BMI}$ is associated with a $12 \%$ risk of discontinuation due to insufficient efficacy (HR 1.12, $95 \%$ $\mathrm{Cl}: 1.01-1.24)$ and a $17 \%$ increase in adverse event risk (HR 1.17, $95 \% \mathrm{Cl}: 1.02-1.36$ ), regardless of the duration of treatment.

Chiam L. Y. T. and co-authors [8] examined 207 patients under 18 years of age with a diagnosis of psoriasis in the medical centers of the Netherlands and Singapore. A significant difference was found when comparing the history of family history in Dutch and Singaporean children $(73.3 \%$ versus $13.6 \%$, respectively). Itching and the presence of provoking factors were also more common among Dutch children (80\% versus $14.2 \%$ and $33.3 \%$ versus $7.4 \%$, respectively). In both study groups, the most common site for psoriasis was the head, followed by the extremities. Similar proportions in children of both groups had nail lesions.

A prospective study of women with psoriasis in the United States was conducted. The study included female nurses who were monitored over a 12-year period, from 1996 to 2008, who answered specific questions about the medical history. The study thus enrolled 67.300 women. Of these, 809 individuals who had a psoriasis debut were selected over the 12 years of follow-up. A positive correlation was found between BMl (both baseline and updated) and the risk of psoriasis (both $p<0.001$ ). Compared with women 
with updated $\mathrm{BMI}<25$, the multivariate relative risk of psoriasis was 1.21 (95\% Cl, 1.03-1.43) for BMI 25.0-29.9, $1.63(95 \% \mathrm{Cl}, 1.33-2.00)$ for BMI 30.0-34.9 and $2.03(95 \%$ $\mathrm{Cl}, 1.58-2.61)$ for BMI 35.0 or more [16].

The results of another experiment revealed a correlation between the severity of psoriasis and the presence of metabolic syndrome. The experiment was conducted with the participation of persons aged $45-65$ years, patients with psoriasis (4065 persons) and healthy persons (40650 persons). The diagnosis and severity of psoriasis were determined using special questionnaires. After selection, groups were formed according to the severity of psoriasis and correlations with metabolic syndrome were studied. Psoriasis has been found to be associated with metabolic syndrome and the power of association is increased with increasing severity of psoriasis (mild $-1.22,95 \% \mathrm{Cl} 1.11$ 1.35; severe $-1.98,95 \% \mathrm{Cl} 1.62-2.43$ ) [19]. The results of this study confirm the data obtained by Zindanci I. with coauthors during a similar experiment [31].

A group of scientists led by Mahé E. [22] examined 126 boys and 135 girls with an average age of 9.8 years in 23 French skin medical centers $(32 \%$ of whom had severe psoriasis). There was also a control group of healthy children. Overweight with an abdominal type of obesity, including obesity $(18.4 \%$ vs. $10.4 \% ; p=0.009)$ and only obesity $(10.0 \%$ vs. $3.1 \%$; $=0.001)$ were more common in psoriasis patients.

Chinese researchers [30] conducted an epidemiological study of 4452 patients and 1166 healthy Han nationals. Prevalence of overweight and obese was observed in patients with psoriasis. The odds ratio was 1.301 (95\% $\mathrm{Cl}, 1.105-1.531)$ and $1.680(95 \% \mathrm{Cl}, 1.134-2.491)$, respectively. The severity of psoriasis, according to the PAS severity index, was statistically correlated with body mass index $(r=0.184, p<0.01)$

Clinical study revealed the distribution of blood groups in patients with various skin diseases. In total, 140 patients with psoriasis, 76 patients with vitiligo, 30 patients with pemphigus, 84 patients with focal alopecia, and 2067 healthy subjects participated in the study. In patients with psoriasis the most common was 0 blood group (37.1\%), followed by $\mathrm{B}(30 \%)$ and $\mathrm{A}(25.7 \%)$ blood group. In patients with alopecia blood group $B$ was found in $45.2 \%$ of patients, blood group 0 in $28.6 \%$ and group $A$ in $19 \%$. In patients with vitiligo, blood group $B$ was found in $47.4 \%$ of patients, blood group 0 in $36.8 \%$ and blood group $A$ in $10.5 \%$. In patients with pemphigus, blood groups 0 and $B$ were detected in $40 \%$ of patients, blood group A in $20 \%$ [28].

In addition, the works of Ukrainian researchers concerning the search for constitutional features in other skin diseases are known [14, 23].

Cherkasov V. G. with co-authors [7] established differences of dermatoglyphic features in girls of 12-17 years, patients with atopic dermatitis of mild and moderate severity in comparison with healthy girls of similar age. Such features are palm patterns, various forms of axial triradius, the frequency of simple, rare and complex finger patterns, the ridge count $a-b$ and $b-c$, the length of the segment $a-d$ and the deviations of the values of the individual palm angles.

In other work, Gunas I. V. and others [11] revealed the peculiarities of constitutional parameters in adolescents suffering from acne. Compared with the control group of healthy individuals, greater values of muscle and bone mass, as well as the mesomorphic component of the somatotype, were found, whereas the indices of body fat and endomorphic component of the somatotype were smaller than those of healthy individuals.

Equally important is the study of the quality of life and the psycho-emotional sphere of persons with psoriasis. It is necessary to understand the relationship between the severity of symptoms and discomfort, stigmatization and quality of life among patients with psoriasis [3, 9, 13, 15, 18, 20].

Böhm D. and others [5] examined 381 patients for this purpose, determined the severity of psoriasis symptoms, degree of discomfort, stigma (according to a special questionnaire) and quality of life index (using DLQI and SF-8 questionnaires). The severity of the symptoms was associated with greater discomfort, stigma, and decreased quality of life. The severity of symptoms was poorly correlated with the more general aspects of the quality of life index as measured by SF-8. Men and women reported different feelings of discomfort, stigma, and psychic aspects of the quality of life index.

Moroccan scientists [12] examined a group of 140 patients with psoriasis who completed the Skindex questionnaire to evaluate changes in quality of life. An analysis of the data collected, which most affected the quality of life index in individuals with severe psoriasis in young women, is attributed to low socio-economic levels, rural living, psoriatic arthritis, head, nail and mucous membrane lesions by psoriasis.

The relationship between emotional intelligence and life satisfaction in people with psoriasis has been determined [2]. The study group consisted of 81 patients (40 men and 41 women) with an average age of 41.22 years. The study used the Emotional Intelligence Questionnaire (INTE), the Satisfaction Scale (SWLS), the Personal Questionnaire, and the PASI Scale. A positive correlation was found between emotional intelligence and life satisfaction in a group of patients with psoriasis. Especially with Factor I - the use of emotions in thinking and procedures, which positively correlates with life satisfaction. Emotional intelligence, along with the percentage of body area affected by the disease, are indicators of life satisfaction in patients with psoriasis.

Kwan Z. et al. [17] investigated whether disease severity and clinical manifestations are associated with stress, depression, anxiety, and quality of life in patients with psoriasis. The severity of the disease was assessed using the PASI severity index. Quality of life and psychological symptoms were determined using the Dermatological 
Quality of Life Index (DLQI) and the Depression Stress Scale (DASS). The study involved 100 people. Statistical analysis showed that head injury by psoriasis is associated with depression (odds ratio of 8.509; $95 \%$ confidence interval of 1.077-67.23) and anxiety (odds ratio of 6.460; $95 \%$ confidence interval of 1.401-29.86). Younger age was associated with an increased risk of depression (mean difference - 8.640; $95 \% \mathrm{Cl}-16.39-0.890$ ), anxiety (mean difference - 11.55; $95 \% \mathrm{Cl}$ - 18.48-4.628), stress (mean difference - 11.44; $95 \% \mathrm{Cl}-19.25-3.628$ ) and a severe deterioration in the quality of life (mean difference - 12.34; $95 \% \mathrm{Cl}-19.55-5.127)$. After adjusting for age and disease severity, anxiety, stress, and depression correlated with a severe impairment of quality of life.

\section{References}

1. Armstrong, A. W., Harskamp, C. T., \& Armstrong, E. J. (2012). The association between psoriasis and obesity: a systematic review and meta-analysis of observational studies. Nutrition \& diabetes, 2 (12), e54. https://doi.org/10.1038/nutd.2012.26.

2. Basi?ska, M. A., \& Drozdowska, M. (2013). Emotional intelligence as an indicator of satisfaction with life of patients with psoriasis. Advances in Dermatology and Allergology/Postepy Dermatologii i Alergologii, 30 (6), 365-372. doi: 10.5114/ pdia.2013.39435.

3. Basinska, M. A., \& Kasprzak, A. (2012). The relationship between strategies of coping with stress and acceptance of illness among patients with psoriasis. Przeglad Dermatologiczny, 99 (6), 692-700.

4. Basko-Plluska, J. L., \& Petronic-Rosic, V. (2012). Psoriasis: epidemiology, natural history, and differential diagnosis. Psoriasis: Targets and Therapy, 2, 67-76.

5. Bohm, D., Stock Gissendanner, S., Bangemann, K., Snitjer, I., Werfel, T., Weyergraf, A., ... \& Schmid-Ott, G. (2013). Perceived relationships between severity of psoriasis symptoms, gender, stigmatization and quality of life. Journal of the European Academy of Dermatology and Venereology, 27 (2), 220-226. https://doi.org/10.1111/j.1468-3083.2012.04451.x

6. Carrascosa, J. M., Vilavella, M., Garcia-Doval, I., Carretero, G., Vanaclocha, F., Dauden, E., ... \& Sanchez-Carazo, J. L. (2014). Body mass index in patients with moderate-to-severe psoriasis in Spain and its impact as an independent risk factor for therapy withdrawal: results of the Biobadaderm Registry. Journal of the European Academy of Dermatology and Venereology, 28 (7), 907-914. https://doi.org/10.1111/jdv.12208.

7. Cherkasov, V. G., Gunas, I. V., \& Gara, A. V. (2015). Phenogenetic aspects of dermatoglyphic changes in atopic dermatitis. The world of medicine and biology, 11 (3-2), 59-63.

8. Chiam, L. Y. T., de Jager, M. E. A., Giam, Y. C., de Jong, E. M. G. J., van de Kerkhof, P. C. M., \& Seyger, M. M. B. (2011). Juvenile psoriasis in European and Asian children: similarities and differences. British Journal of Dermatology, 164 (5), 11011103. https://doi.org/10.1111/j.1365-2133.2010.10196.x.

9. Colombo, D., Caputo, A., Finzi, A., Andreassi, L., Chimenti, S., Vena, G. A., ... \& PSYCHAE Study Group. (2010). Evolution of and risk factors for psychological distress in patients with psoriasis: the PSYCHAE study. International journal of immunopathology and pharmacology, 23 (1), 297-306. https:/ /doi.org/10.1177/039463201002300128.

10. Ejaz, A., Suhail, M., \& Iftikhar, A. (2016). Psoriasis in Pakistani population: Associations, comorbidities, and hematological profile. Journal of Pakistan Association of Dermatology, 23 (1), 42-46.

11. Gunas, I., Majewski, O., \& Makarchuk, I. (2016). Features of

\section{Conclusions and prospects for further development}

1. A review of the literature indicates the current state of the problem of such a disease as psoriasis, which is not only a skin lesion but also a serious socio-psychological problem. Given its chronic nature, lack of etiopathogenetic treatment, and knowing the trigger factors in the right way, it would be a good idea to look for early predisposition for the disease and to form risk groups for such individuals. Ideal in terms of efficiency and cheapness, given the results of the above studies, could be anthropological studies.

Studying the constitutional features of the occurrence and course of psoriasis for the population of Ukraine is thus a priority and topical area of research.

somatotype and body weight component composition in patients with acne: boys and girls of Podillya region of Ukraine. Current Issues in Pharmacy and Medical Sciences, 29 (2), 97-100. DOI: 10.1515/cipms-2016-0020.

12. Kelati, A., Meziane, M., Mounir, J., \& Zahra, M. F. (2016). The impact of psoriasis on the lifequality: a cohort of 140 Moroccan patients. Our Dermatology Online, 7 (1), 10-16. DOI:10.7241/ ourd.20161.3.

13. Korman, N. J., Zhao, Y., Pike, J., \& Roberts, J. (2016). Relationship between psoriasis severity, clinical symptoms, quality of life and work productivity among patients in the USA. Clinical and experimental dermatology, 41 (5), 514-521. https:// doi.org/10.1111/ced.12841.

14. Kryvko, Y. Y., Gunas, I. V., Vastyanov, R. S., \& Chaplyk-Chyzho, I. O. (2016). Simulation using discriminant analysis the course of pyoderma in men and women of western region of Ukraine depending on the characteristics of constitutional parameters of body. Journal of Education, Health and Sport, 6 (6), 599605. http://dx.doi.org/10.5281/zenodo.56742.

15. Kumar, S., Akhtar, T., Islam, W. A., Chopra, D., \& Kaur, R. (2017). Quality of life evaluation in women Psoriatic patients. Int. J. of Life Sciences, 5 (1), 93-96.

16. Kumar, S., Han, J., Li, T., \& Qureshi, A. A. (2013). Obesity, waist circumference, weight change and the risk of psoriasis in US women. Journal of the European Academy of Dermatology and Venereology, 27 (10), 1293-1298. https://doi.org/10.1111/ jdv.12001.

17. Kwan, Z., Bong, Y. B., Tan, L. L., Lim, S. X., Yong, A. S. W., Ch'ng, C. C., ... \& Ismail, R. (2018). Determinants of quality of life and psychological status in adults with psoriasis. Archives of dermatological research, 310 (5), 443-451. https://doi.org/ 10.1007/s00403-018-1832-x.

18. Kwan, Z., Bong, Y. B., Tan, L. L., Lim, S. X., Yong, A. S. W., Ch'ng, C. C., ... \& Ismail, R. (2017). Socioeconomic and sociocultural determinants of psychological distress and quality of life among patients with psoriasis in a selected multi-ethnic Malaysian population. Psychology, health \& medicine, 22 (2), 184-195. https://doi.org/10.1080/ 13548506.2016.1220603.

19. Langan, S. M., Seminara, N. M., Shin, D. B., Troxel, A. B., Kimmel, S. E., Mehta, N. N., ... \& Gelfand, J. M. (2012). Prevalence of metabolic syndrome in patients with psoriasis: a populationbased study in the United Kingdom. Journal of Investigative Dermatology, 132 (3), 556-562. https://doi.org/10.1038/ jid.2011.365

20. Leibovici, V., Canetti, L., Yahalomi, S., Cooper-Kazaz, R., Bonne, O., Ingber, A., \& Bachar, E. (2010). Well being, psychopathology and coping strategies in psoriasis compared with atopic 
dermatitis: a controlled study. Journal of the European Academy of Dermatology and Venereology, 24 (8), 897-903. https:// doi.org/10.1111/j.1468-3083.2009.03542.x.

21. Levi, S. S., \& Ramot, Y. (2018). Gender differences in psoriasis. In Gender and dermatology (pp. 63-81). Springer, Cham.

22. Mahe, E., Beauchet, A., Bodemer, C., Phan, A., Bursztejn, A. C., Boralevi, F., ... \& Vabres, P. (2015). Psoriasis and obesity in French children: a case-control, multicentre study. British Journal of Dermatology, 172 (6), 1593-1600. https://doi.org/ 10.1111/bjd.13507

23. Makarchuk, I. M., Maevsky, O. Ye., \& Gunas, I. V. (2016) Simulation using discriminant analysis possibilities of disease and features course of acne in boys from Podillya. Reports of Morphology, 22 (1), 160-163.

24. Michalek, I. M., Loring, B., \& John, S. M. (2017). A systematic review of worldwide epidemiology of psoriasis. Journal of the European Academy of Dermatology and Venereology, 31 (2), 205-212. https://doi.org/10.1111/jdv.13854.

25. Parisi, R., Symmons, D. P., Griffiths, C. E., \& Ashcroft, D. M. (2013). Global epidemiology of psoriasis: a systematic review of incidence and prevalence. Journal of Investigative Dermatology, 133 (2), 377-385. https://doi.org/10.1038/ jid.2012.339.

26. Puig, L. (2011). Obesity and psoriasis: body weight and body mass index influence the response to biological treatment. Journal of the European Academy of Dermatology and
Venereology, 25 (9), 1007-1011. https://doi.org/10.1111/j.14683083.2011.04065.x.

27. Rachakonda, T. D., Schupp, C. W., \& Armstrong, A. W. (2014) Psoriasis prevalence among adults in the United States. Journal of the American Academy of Dermatology, 70 (3), 512-516. https://doi.org/10.1016/j.jaad.2013.11.013.

28. Rather, P. A., Hassan, I., Naaz, S., Rasool, F., \& Reshi, R. (2016) Evaluation of $\mathrm{ABO}$ blood types in various dermatoses in Kashmiri population: A case-control study. Journal of Pakistan Association of Dermatology, 24 (3), 224-230.

29. Tollefson, M. M., Crowson, C. S., McEvoy, M. T., \& Kremers, H. M. (2010). Incidence of psoriasis in children: a populationbased study. Journal of the American Academy of Dermatology, 62 (6), 979-987. https://doi.org/10.1016/ j.jaad.2009.07.029

30. Zhang, C., Zhu, K. J., Zheng, H. F., Cui, Y, Zhou, F. S., Chen, Y L., ... \& Zuo, X. B. (2011). The effect of overweight and obesity on psoriasis patients in Chinese Han population: a hospitalbased study. Journal of the European Academy of Dermatology and Venereology, 25 (1), 87-91. https://doi.org/ 10.1111/j.1468-3083.2010.03706.x.

31.Zindanci, I., Albayrak, O., Kavala, M., Kocaturk, E., Can, B., Sudogan, S., \& Koc, M. (2012). Prevalence of metabolic syndrome in patients with psoriasis. The Scientific World Journal. http://dx.doi.org/10.1100/2012/312463.

\section{КОНСТИТУЦІОНАЛЬНІ ОСОБЛИВОСТІ ВИНИКНЕННЯ ТА ПЕРЕБІГУ ПСОРІАЗУ (АНАЛІЗ НАУКОВОЇ ЛІТЕРАТУРИ) \\ Обадех Бассам Абдель-Рахман Аль-Каралех}

Анотація. Мета роботи - провести аналіз наукової літератури щодо конституціональних особливостей виникнення та перебігу псоріазу. Проведено аналіз сучасної наукової літератури в наукометричних базах PubMed, eLIBRARY.RU $i$ Web of Science. Проведений огляд літературних джерел вказує на сучасний стан проблеми такого захворювання як псоріаз, яке являє собою не тільки ураження шкіри, але і тяжку соціально-психологічну проблему. Враховуючи його хронічну природу, відсутність етіопатогенетичного лікування та знаючи тригерні фрактори, вірним був би шлях пошуку методів раннього передбачення схильності до даного захворювання та фрормування для таких осіб груп ризику. Ідеальним, зважаючи на ефективність і дешевизну, враховуючи результати вищенаведених міркувань, могли б стати антропологічні дослідження. Вивчення конституціональних особливостей виникнення та перебігу псоріазу для населення України, таким чином, є пріоритетним та актуальним напрямком дослідження.

Ключові слова: псоріаз, виникнення, перебіг, клінічна антропологія, якість життя.

\section{КОНСТИТУЦИОНАЛЬНЫЕ ОСОБЕННОСТИ ВОЗНИКНОВЕНИЯ И ТЕЧЕНИЯ ПСОРИАЗА (АНАЛИЗ НАУЧНОЙ ЛИТЕРАТУРЫ) Обадех Бассам Абдель-Рахман Аль-Каралех}

Аннотация. Цель работы - провести анализ научной литературы по конституциональным особенностям возникновения и mечения псориаза. Проведен анализ современной научной литературы в наукометрическux базах PubMed, eLIBRARY.RU u Web of Science. Проведенный обзор литературных источников указывает на современное состояние проблемы такого заболевания как псориаз, которое представляет собой не только поражения кожи, но и тяжелую социально-психологическую проблему. Учитывая его хроническую природу, отсутствие этиопатогенетического лечения и зная триггерные фракторы, правильным был бы путь поиска методов раннего предсказания склонности к данному заболеванию и формирования для таких лиц групп риска. Идеальными, принимая во внимание эфффективность и дешевизну, учитывая результать вышеприведенных исследований, могли бы стать антропологические исследования. Изучение конституциональных особенностей возникновения и течения псориаза для населения Украины, таким образом, является приоритетным и актуальным направлением исследования.

Ключевые слова: псориаз, возникновение, течение, клиническая антропология, качество жизни. 